Dhaka Univ. J. Biol. Sci. 22(1): 39-46, 2013 (January)

\title{
MYCOFLORA ASSOCIATED WITH TWO SPECIES OF LILIACEAE IN BANGLADESH
}

\author{
SHAMIM SHAMSI*AND NAJMUN NAHER ${ }^{1}$ \\ Department of Botany, University of Dhaka, Dhaka-1000, Bangladesh
}

Key words: Mycoflora , Hemerocallis fulva, Pancratium verecundum, Liliaceae, Bangladesh

\begin{abstract}
A total of nine fungi were isolated from two ornamental angiosperms, namely Hemerocallis fulva L. and Pancratium verecundum Ant. belong to Liliaceae. Three species of fungi were found to be associated with the leaf of Hemerocallis fulva. The fungi were Colletotrichum capsici, (Syd.) Bull. \& Bisby, Colletotrichum dematium (Pers. Ex Fr.) and Glomerella montana (Sacc.)v Arx \& E. Muller. Six species of fungi, namely Alternaria alternata (Fries) Keissler, Colletotrichum orbiculare (Berk \& Mont.) Arex., Curvularia clavata Jain, Fusarium solani (Mort.) Sacc., Lasiodiplodia theobromae (Pat.) Griffon and Maubol and Macrophomina phaseolina (Tassi) Goid were found to be associated with P. verecundum. Among the fungal species Glomerella montana is new record for Bangladesh.
\end{abstract}

\section{Introduction}

Species of Liliaceae are most common and attractive ornamental plants. Certain lilies are susceptible to fungal diseases such as anthracnose, botrytis blight, blue mold, powdery mildew and rust. Lily plants are also attacked by Fusarium sp., Cylindrocarpon sp. and Sclerotium sp.. These fungi weaken the plant over the time and can eventually kill it ${ }^{(1)}$. Hemerocallis fulva L. is a showy herb with short bulbous root stock and fleshy leaves. Its local name is 'Kamla lily' and flowers during June - July in Bangladesh. Plants grow well in hilly regions and well drained soil. Plant is distributed in South Europe, North Asia to Japan. The ornamental is cultivated throughout the Indian subcontinent, especially in the Himalayas and Khasia hills. Pancratium verecundum Ant. is a bulbous annual herbs with white flower. Normally, it grows in hilly area and flowers during March - July. The plant is distributed in the foot of Himalayas, from Punjab to eastward to Sikkim and Assam. Children eat the sweet nectar accumulated in perienth tube ${ }^{(2)}$. Lily is most common ornamental plant in Bangladesh. A lot of research have been done on taxonomy of the lily plants(3). Two economically important members of Lilyaceae viz., Allium cepa and Allium sativum are attacked by the species of Aspergillus and Colletotrichum but report on fungal diseases of Hemerocallis fulva and Pancratium verecundum is not available in the literatures. Present study was undertaken to find out the presence of pathogenic fungi with lily plants in Bangladesh.

*Author for correspondence: <prof.shamsi@gmail.com>. ${ }^{1}$ Department of Botany, Life and Earth Science Group, National University, Gazipur-1704, Bangladesh. 


\section{Materials and Methods}

During March, 2009 to July, 2010 infected leaves of Hemerocallis fulva and Pancratium verecundum were collected from the Botanical Garden, University of Dhaka and Gulshan area, Dhaka. The samples were directly examined under a compound microscope. Twenty five samples were examined from infected leaves of two species of lily plants. Fungi associated with infected leaves of lily were also isolated following "Tissue planting" and "Blotter" methods ${ }^{(4)}$. Potato dextrose agar (PDA) medium was used for "Tissue Planting" method. From a particular sample 30 inocula, each measuring $2^{2} \mathrm{~mm}$ were cut and kept in a sterile Petri plate. The inocula were washed in sterile water and then surface sterilized by dipping in 10\% chlorox for 3 - 5 minutes and rinsed with sterilized water. Three pieces of leaf samples were placed in each plate containing PDA medium and on sterilized plate with moist filter paper. Petri plates were incubated at $25 \pm 1^{\circ} \mathrm{C}$ for $5-7$ days. Fungi grew from the inocula were transferred to separate plates and slants for further studies and preservation. For microscopic observations of fungal structures, temporary mount was prepared in lacto phenol on a clean slide. In case of hyaline structures, a little amount of aniline blue was added to the mounting fluid. The isolated fungi were identified comparing the morphological characteristics recorded during microscopic observation with standard keys ${ }^{(5-9)}$.

All the specimens were preserved in the Herbarium, Mycology and Plant Pathology Division, Department of Botany, University of Dhaka, Bangladesh.

\section{Results and Discussion}

Three species of fungi were associated with the leaves of Hemerocallis fulva showing anthracnose symptom. The fungi were, namely Colletotrichum capsici, C. dematium and Glomerella montana. Healthy and infected plants of $H$. fulva with associated fungi are presented in Fig. 1. A-G. Six species of fungi namely, Alternaria alternata, Colletotrichum orbiculare, Curvularia clavata, Fusarium solani, Lasideplodia theobromae and Macrophomina phaseolina were associated with infected leaves of P. verecundum (Figs 2A- F and 3A- F).

Alternaria alternata, Colletotrichum capsici, C. dematium, C. orbiculare, Curvularia clavata, Fusarium solani, Lasideplodia theobromae and Macrophomina phaseolina are well documented plant pathogens having wide host range and also reported from Bangladesh other than lily plants ${ }^{(10-11)}$. This is the first record of association of all the fungi with lily in Bangladesh. The species of Glomerella montana is new record for Bangladesh. Descriptions of the identified fungi are summarized below.

Alternaria alternata (Fries) Keissler

(Fig. 2F)

Colony greyish green, reverse blackish green, Mycelia brown, septate, conidiophores dark brown, simple, mostly short, septate up to $50 \mu \mathrm{m}$ long, $3-6 \mu \mathrm{m}$ thick with a scar at the tip. Conidia dark brown, typically with both cross and longitudinally septate, 
variously shaped, obclavate to elliptical or ovoid, mostly verruculose, 20 - $63(38) \times 9-19$ (13) $\mu \mathrm{m}$.

Specimen examined: Isolated from infected leaves of Hemerocallis fulva. N. Naher 33.
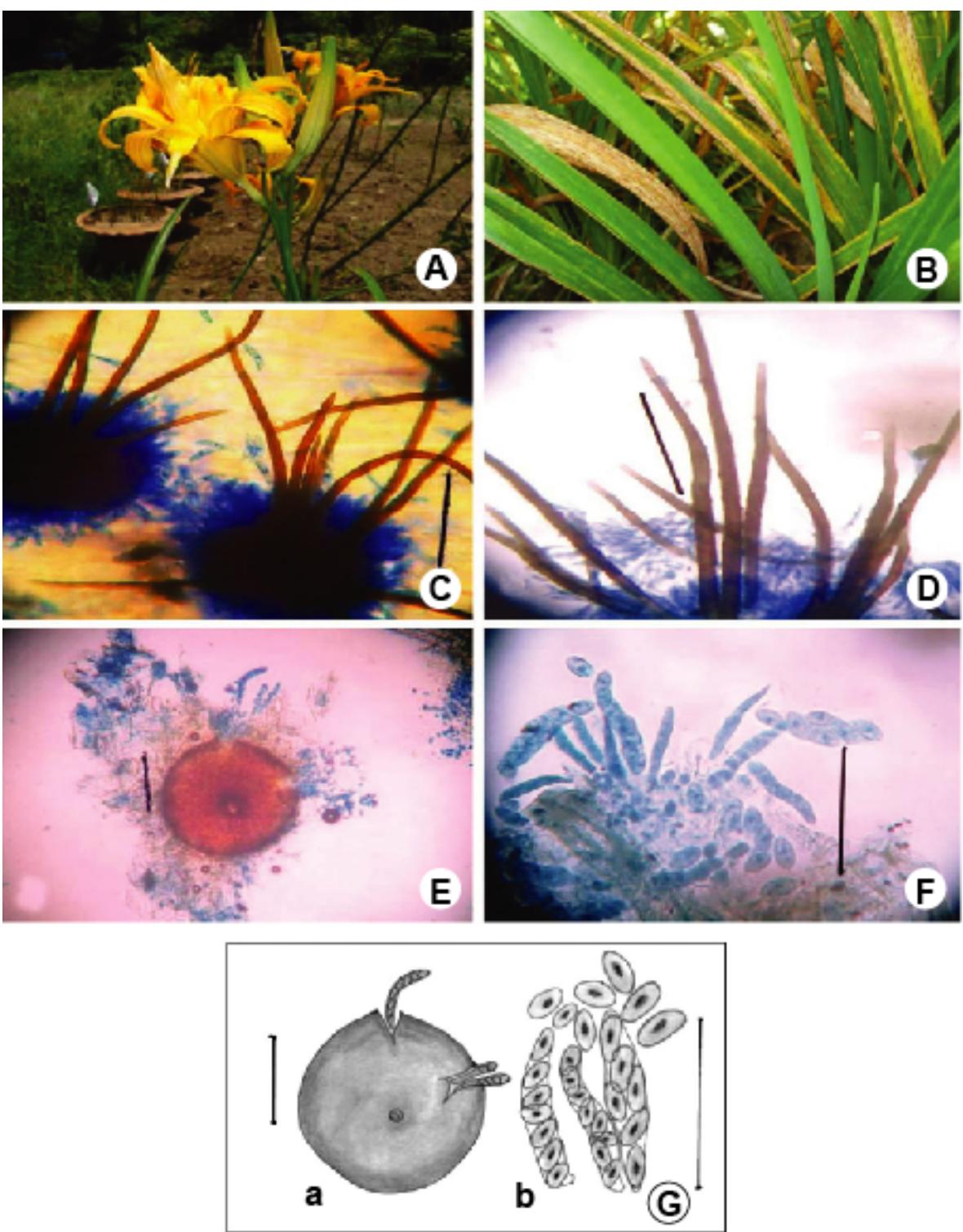

Fig. 1A - G. A, healthy plants. B, infected leaves of Hemerecallis fulva. C, characteristics of acervulli of Colletotrichum capsici. D, Colletotrichun dematium. E, perithecium of Glomerella montana. F, asci containing ascospores of G. Montana [Bars $=50 \mu \mathrm{m}(\mathrm{C}, \mathrm{D}, \mathrm{F})$ and $100 \mu \mathrm{m}(\mathrm{E})] . \mathrm{G},(\mathrm{a}-\mathrm{b})$, Camera lucida drawing of perithecium, asci containing ascospores of G. Montana [Bars $=11 \mu \mathrm{m}$ (a) and $25 \mu \mathrm{m}(\mathrm{b})]$. 

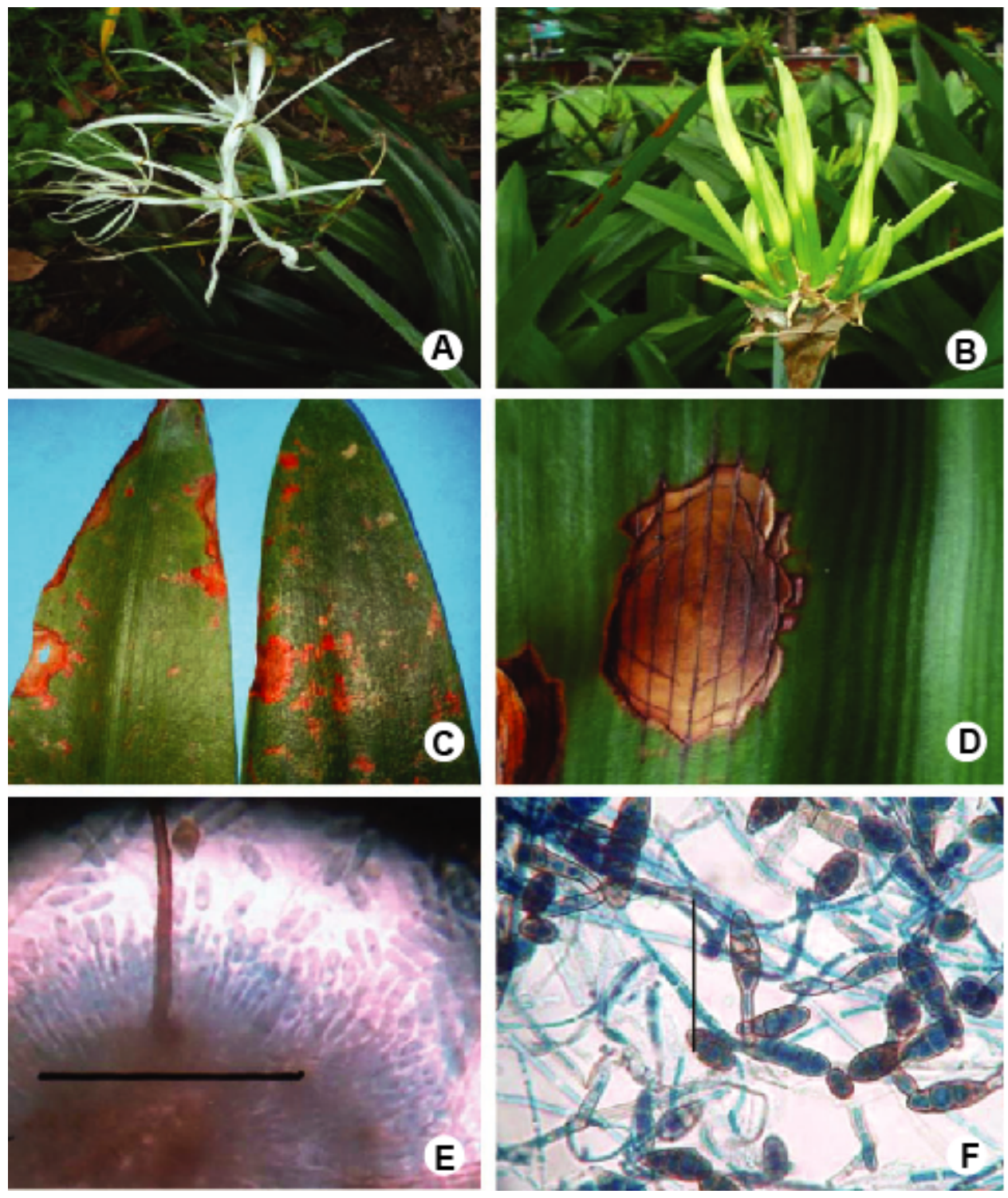

Fig. 2A-F. A, healthy plants; B, anthracnose infected plants. C, anthracnose infected leaves. D, enlarged view of lesion on anthracnose infected leaf of Pancrtium verecundum. E, characteristics of acervulli of Colletotrichum orbiculare, F, conidiophores and conidia of Alternaria alternata [Bars $=50 \mu \mathrm{m}]$.

Colletotrichum capsici (Syd.) Bult. \& Bisby

(Fig. 1C)

Colony dense whitish, dark grey at maturity on PDA medium, reverse dark brown, mycelia dark grey, branched septate, conidial masses buff to salmon. Sclerotia absent. Acervulus developed on PDA medium after 20 days of inoculation at $25-28^{\circ} \mathrm{C}$ 
temperature. Setae abundant, dark brown, septate. Conidia falcate, fusiform, hyaline apices acute, $17-24 \times 3-4 \mu \mathrm{m}$. Appressoria abundant, medium brown, clavate to circular, edge usually entire, $9-15 \times 7-12 \mu \mathrm{m}$.

Specimen examined: Isolated from infected leaves of Hemerocallis fulva. N. Naher 34.

Colletotrichum dematium (Pers. ex Fr.) Grove

(Fig. 1D)

Colony dense whitish, dark grey at maturity on PDA medium, reverse dark brown, Mycelia dark grey, branched, conidial masses buff to salmon. Scerotia absent. Acervulus developed on PDA medium after 20 days of inoculation at $25-28^{\circ} \mathrm{C}$ temperature. Setae abundant, dark brown, septate. Conidia falcate, fusiform, apices acute, hyaline, $23-29 \times 3-4 \mu \mathrm{m}$. Appresoria abundant, medium brown, clavate to circular, edge usually entire, $9-15 \times 7-12 \mu \mathrm{m}$, often becoming complex and forming long closely branched chains.

Specimen examined: Isolated from the healthy leaves of Hemerocallis fulva. S. Shamsi. 2065.

The fungus is known from a wide range of hosts in different families and is found extremely in the tropics and subtropics of Africa, Asia, America and Australia.

Colletotrichum orbiculare (Berk \& Mont.) Arex.

(Fig. 2E)

Colonies grayish white, mycelia pale brown, branched, septate, conidial masses salmon pink. Conodiophores short, hyaline, setae dark brown, abundant, conidia straight, hyaline, aseptate, oblong, $13-14 \times 4-5 \mu \mathrm{m}$. Appressoria dark brown, $9-10 \times 4$ $6 \mu \mathrm{m}$, clavate or irregular, some times becoming complex.

Specimen examined: Isolated from infected leaves of Pancratum verecundum. S. Shamsi 2168.

Glomerella montana (Sacc.)v. Arx \& E. Mulle

(Fig. 1 E-G)

(Teleomorph of Colletotrichum spp.)

Colony grayish black, perithecia brown-black, superficial, solitary or in groups obpyriform to ovate, asci hyaline, $42-72 \times 9-11 \mu \mathrm{m}$. Ascospores hyaline, one celled, mostly $14-17 \times 6-8 \mu \mathrm{m}$.

Specimen examined: Isolated from the leaves of Hemerocallis fulva. N. Naher 43.

The fungus was recorded on dead leaves, May to June. Plurivorous species, recorded on Sesleria including the stripe smut Ustilago striiformis and the hyphomycetes Periconia hispidula.

Curvularia clavata Jain.

(Fig. 3A)

Colonies effuse, grayish black. Conidiophores solitary, mostly unbranched, straight or slightly undulated, brown, septate up to $121 \mu \mathrm{m}$ long, $5-7 \mu \mathrm{m}$ thick. Conidia 
mostly 3 septate, olivaceous brown, slightly curved, third cell from the base is broader and darker than others, smooth, $17-28 \times 7-13 \mu \mathrm{m}$.

Specimen examined: Isolated from infected leaves of Pancratium verecundum. N. Naher 25 .
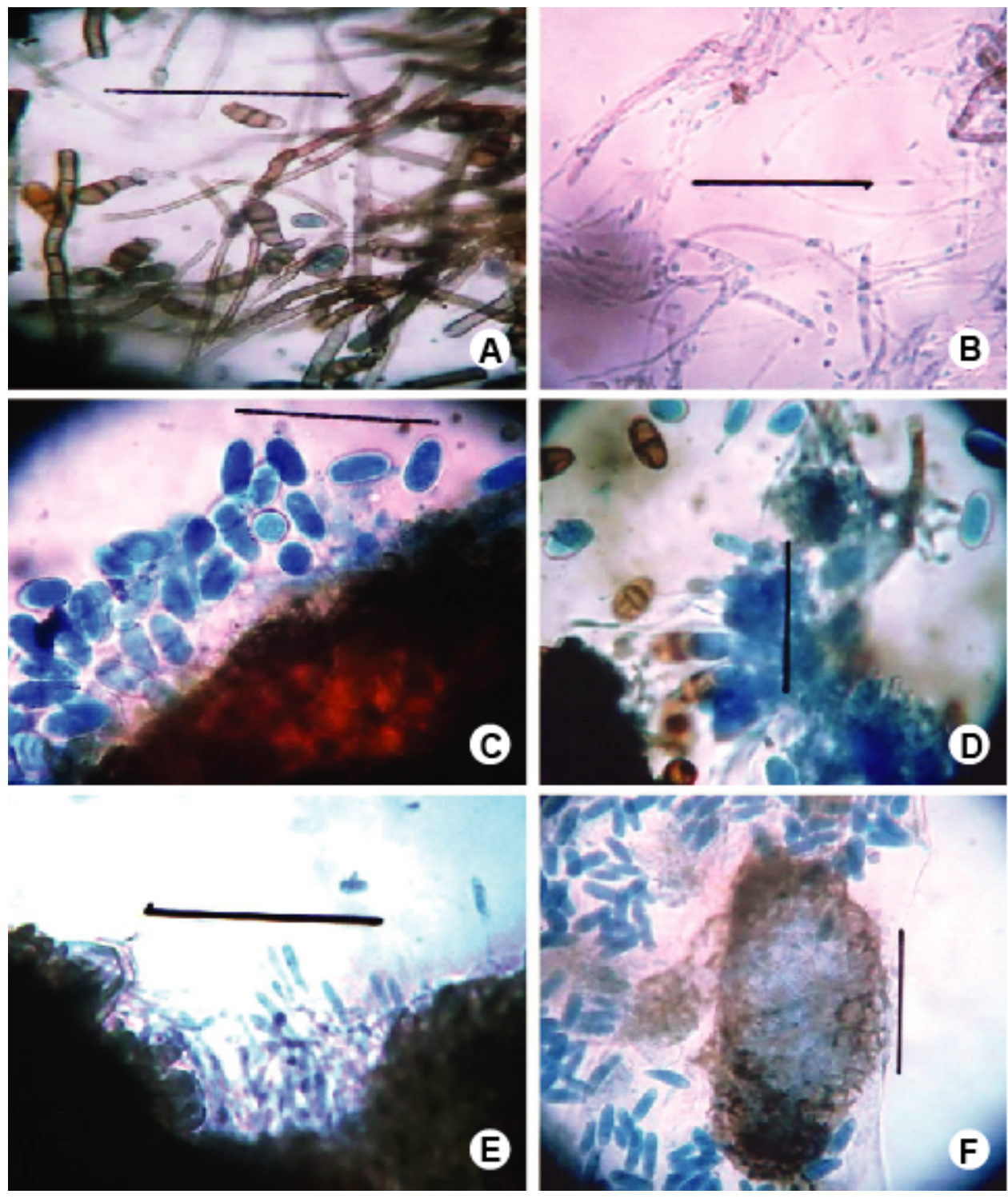

Fig. 3A-F. A, showing conidiophores and conidia of Curvularia clavata. B, phialide and conidia of Fusarium solani. C-D, pycnidia with conidiophores bearing conidia of Lasiodiplodia theobromae and E- F, pycnidia with conidiophores bearing conidia of Macrophomina phaseolina associated with Pancrtium verecundum [Bars $=50 \mu \mathrm{m}]$. 
Fusarium solani (Mort.) Sacc.

(Fig. 3B )

Colonies white but with some tinge of pink at maturity, cottony. Mycelium hyaline, sepatate, branched. Conidiophores hyaline short, branched, bearing phialedes. Conidia hyaline, micrconidia mostly two celled, ovoid or oblong, borne singly. Macroconidia hyaline mostly 3 celled, typically canoe shaped.

Specimen examined: Isolated from infected leaves of Pancratium verecundum. S. Shamsi 2169.

Lasiodiplodia theobromae (Pat.) Griffon and Maubol.

(Fig. 3C, D)

(Syn. Botryodiplodia theobromae Pat.)

Colony graish brown, reverse blackish brown. Pycnidia black ostiolate, erumpent. Conodiophores simple, short, conidia hyaline 1- but 2-celled and dark a maturity, ovoid to elongate.

Specimen examined: Isolated from infected leaves of Pancratium verecundum. S. Shamsi 2180.

Macrophomina phaseolina (Tassi) Goid.

(Fig. 3E, F)

Colony grayish black, reverse grayish black, mycelia brown, septate, pycnidia dark, ostiolate, small, globose erumpent, 0.1-0.2 mm diam. Conidiophore short, hyaline. Conidia hyaline, 1 -celled, ovoid to broadly ellipsoidal $13-28 \times 5-11 \mu \mathrm{m}$.

Specimen examined: Isolated from infected leaves of Pancratium verecundum. S. Shamsi 2185.

\section{References}

1. Boerema GH and ECH Maria 1988. Check-list for scientific name of common parasitic fungi series 3a: Fungi on bulbs: Liliaceae, Neth. J. Plant. Path. 94(1): 1-32.

2. Westcott, Cynthia, and R. Kenneth Horst. 1979. Westcott's Plant disease handbook. New York: Van Nostrand Reinhold.

3. Siddique KU MA Ismail, ZU Ahmed, ZNT Begum, MA Hassan, M Khondker, MM Rahman, SMH Kabir, M Ahmed, ATA Ahmed, AKA Rahman, and EU Haque. (eds) 2007. Encyclopedia of Flora and Fauna of Bangladesh. 11. Angiosperms; Monocotyledons Agavaceae- Najadaceae. Asiatic Society of Bangladesh.

4. CAB (Commonwealth Agricultural Bureau) 1968. Plant Pathologists Pocket Book. The Commonwealth Mycological Institute, Kew Surrey.

5. Booth C 1971. The Genus Fusarium. The commonwealth Mycological Institute, England.

6. Ellis MB 1971. Dematiaceous Hyphomycetes. The Commonwealth Mycological Institute, England.

7. Ellis MB 1976. More Dematiaceous Hyphomycetes. The Commonwealth Mycological Institute, England.

8. Ellis MB and JP Ellis 1997. Microfungi on Land Plants. Richmond Publishing Co. Ltd. 
9. Sutton BC 1980. The Coelomycetes. Fungi Imperfect with Pycnidia Acervuli and stroma, Commonwealth Mycological institute, Kew Surrey, England.

10. Siddiqui KU Islam, M.A Begum, ZNA Hassan, MA Khandker, M Rahman, M.M Kabir, SMH Ahmad, M Ahmed, ATA Rahman, AKA and EU Haque. (eds.) 2007. Encyclopedia of flora and fauna of Bangladesh. Vol.2. Cyanobacteria, Bacteria andFungi. Asiatic Society of Bangladesh, Dhaka. 415 pp (one of the contributor of chapter fungi).

11. Shamsi S and S Sharmin 2012. Fungal diseases of Groundnut from Bangladesh. Lambert Academic Publishing.

(Manuscript received on 23 May, 2012; revised on 14 November, 2012) 